\title{
QUANTITATIVEETHNOBOTANY OF A RESTINGA FOREST FRAGMENT in Rio de JANEIRo, BraZiL
}

\author{
Viviane Stern da Fonseca-Kruel, Dorothy Sue Dunn de Araujo ${ }^{2}$, \\ Cyl Farney Catarino de Sál \& Ariane Luna Peixoto ${ }^{3}$
}

\begin{abstract}
(Quantitative ethnobotany of a restinga forest fragment in Rio de Janeiro, Brazil) An ethnobotanical study was carried out in the local fishing community of Arraial do Cabo Municipality, starting with an inventory of a resting a forest remnant adjacent to the community being studied. Using quantitative ethnobotany methodology allied with ecological parameters (frequency, density, dominance and their relative values, importance value index), we sampled 296 individuals and identified 41 species in 26 families and 36 genera. The highest use value (U.V.) was attributed to Schinus terebinthifolius Raddi. Based on these data we interviewed local fishermen regarding useful species. We used structured interviews and quantitative analysis based on informant consensus. The 22 different types of usage mentioned were placed in five categories: food, medicine, technology, construction and firewood. Selective extraction of wood for construction, firewood and boat repair were the most important use values, involving $46 \%$ of the species, $57 \%$ of the families and $80 \%$ of the individuals.

Key words: fishing colony, ecological ethnobotany, vegetation structure, restinga, extractivist reserve.

\section{Resumo}

(Etnobotânica quantitativa de um fragmento de floresta de restinga no Rio de Janeiro, Brasil) Um estudo etnobotânico foi feito na comunidade de pescadores artesanais do município de Arraial do Cabo, começando com o inventário de espécies, desenvolvido em um remanescente de floresta de restinga próximo à comunidade estudada. Usando uma metodologia quantitativa em Etnobotânica, aliada a parâmetros ecológicos (freqüência, densidade, dominância e seus valores relativos, e índice de valor de importância), os seguintes resultados foram obtidos: 296 indivíduos foram inventariados e 41 espécies identificadas, distribuídas em 26 famílias e 36 gêneros. O maior valor de uso (V.U.) foi atribuído a Schinus terebinthifolius Raddi. A partir destes dados, foram realizadas entrevistas estruturadas, e análises quantitativas, baseadas no consenso entre os informantes (pescadores locais) para buscar indicação sobre as espécies úteis. Os 22 diferentes tipos de uso mencionados foram distribuídos em cinco categorias: alimentar, medicinal, tecnologia, construção e combustível. Os valores de uso mais expressivos, envolvendo $46 \%$ das espécies, $57 \%$ das famílias e $80 \%$ dos indivíduos, foram relativos à extração seletiva de madeira para construção, lenha e reparo de barcos.
\end{abstract}

Palavras-chave: pescadores artesanais, etnobotânica ecológica, fitossociologia, restinga, reserva extrativista.

\section{INTRODUCTION}

Recent ethnobotanical investigations have emphasized the need for quantitative studies to support the maintaince of biodiversity and the traditional knowledge associated with it (e.g., Phillips \& Gentry 1993 a,b ; Figueiredo et. al. 1993; Begossi 1996; Chazdon \& Coe 1999; Hanasaki et. al. 2000; Galeano 2000; Cunha \& Albuquerque 2006). Many different methodological approaches are used (Phillips
1996) including: a) informant consensus - the relative importance of each use is calculated directly from the degree of consensus among informants; b) subjective allocation - the relative importance of each use is assigned subjectively by the researcher; and c) summed uses - no attempt is made to quantify the relative importance of each use; they are simply added up according to plant-use category, taxonomic group or vegetation type.

Artigo recebido em 05/2008. Aceito para publicação em 02/2009.

${ }^{1}$ Instituto de Pesquisas Jardim Botânico do Rio de Janeiro, R. Pacheco Leão 915, Jardim Botânico, 22460-030, Rio de Janeiro, RJ, Brasil.E-mail: vfonseca@jbrj.gov.br

${ }^{2}$ Universidade Federal do Rio de Janeiro, Depto. Ecologia, C.P. 68020, 21941-590, Rio de Janeiro, RJ, Brasil. E-mail: dotaraujo@globo.com

${ }^{3}$ Universidade Federal Rural do Rio de Janeiro, Depto. Botânica, C.P. 74582, 23851-970, Seropédica, RJ, Brasil. E-mail: alpeixoto@terra.com.br 
Studies using quantitative methodology in the Neotropics (e.g., Balée 1986, 1987; Prance et al. 1987; Boom 1990) have demonstrated the need to protect plant families such as Arecaceae, Lecythidaceae, Chrysobalanaceae, and Malpighiaceae that are widely used by indigenous groups. In Peru, Phillips \& Gentry (1993 a,b) and Phillips et al. (1994) developed a quantitative method whereby the use value (UV) of each family was estimated from the number of plants assigned to different categories (construction, trade, food, technology and medicine). UV analysis was adapted by Galeano (2000) in Colombia using informant consensus for useful species and families. On the coast of Southeast Brazil, ethnobotanical studies have used diversity indices to compare the diversity of traditional knowledge with that of plant use (e.g., Begossi et al. 1993; Figueiredo et al. 1993, 1997; Lima et al. 2000; Rossato et al. 1999; Hanazaki et al. 2000, Albuquerque \& Andrade 2002a, b).

Rio de Janeiro state lies in a transition zone between two major coastal regions. It is very diverse in terms of geomorphology and climate, with a rich flora and a variety of vegetation types (Araujo 2000). The restingas (sandy coastal plains of marine Quaternary origin plus the vegetation that grows there) occupy an area of c. $1200 \mathrm{~km}^{2}$, or $2.8 \%$ of the state's total area (Araujo \& Maciel 1998). This is one of the most endangered Brazilian coastal ecosystems due to intense land use by tourism and real estate speculation (Araujo 1997).

Many fishing villages located on or near the restingas make use of local plants even today. These communities depend basically on fishing, subsistence agriculture, and fruits gathered in the wild or from home gardens. Local fishing communities, like other similar traditional communities, have been the subject of field studies in the social and biological sciences (e.g., Diegues 1994; Adams 2000; Prado 2002; Silva 2000). These studies discuss issues involving nature conservation and natural resource use linked to local fishing communities.
Human activities are seriously threatening both the restingas and the fishing communities with their traditional knowledge. Predatory tourism and real-estate speculation have led to the loss of traditional knowledge and to rampant environmental degradation, with a subsequent decline in cultural and biological diversity. This knowledge has been transmitted from father to son over the years, but studies show that the younger generation is no longer interested in traditional knowledge and it may be lost in the future (Lima et al. 2000; Prado 2002; Adams 2000; Fonseca-Kruel \& Peixoto 2004). Clearly ethnobotanical and floristic studies in restingas are urgently needed.

Given this background, we surveyed the flora and vegetation structure of a remnant area of restinga forest so as to assess how local fishermen use the plant life of this area. We quantified plant and plant-product use from the point of view of this traditional fishing community, thus establishing a relationship between the availability and diversity of plant resources.

\section{Material and Methods}

\section{Study Area}

The study area consists of a remnant restinga forest lying c. $700 \mathrm{~m}$ from the ocean in Arraial do Cabo Municipality, Rio de Janeiro (22 $2^{\circ} 6^{\prime} \mathrm{S}$; 42 $2^{\circ} 05^{\prime} \mathrm{W}$ ) bordering the Arraial do Cabo Marine Extractivist Reserve (Resex). This conservation unit was created on January 30, 1990 (Federal Decree $n^{\circ}$ 98.897) to protect the livelihood of local fishermen and to preserve the flora and fauna.

The 1500-square-kilometer Cabo Frio region, which includes Arraial do Cabo Municipality, is one of 14 Brazilian Centers of Plant Diversity (Araujo 1997). Sandy coastal plains, dunes (up to $20 \mathrm{~m}$ ), alluvial deposits and large lagoons (e.g., Araruama $-200 \mathrm{~km}^{2}$ ) dominate this region (Araujo 2000). The beach-ridge system that stretches between the villages of Arraial do Cabo and Saquarema is known as Massambaba Restinga, and consists of two ridges of different ages, with a dune field covering the eastern extremity of the older ridge (Turcq et al. 1999). 
Mean annual rainfall is $823 \mathrm{~mm}$ and is fairly evenly distributed throughout the year; mean annual temperature is $23^{\circ} \mathrm{C}$ with relative humidity $83 \%$ (data from the Cabo Frio weather station). Winds are fairly constant (58\%) and mainly from the northeast. The local climate is a variation of Koeppen's Bsh type, that is, hot and semi-arid (Barbiére 1984).

Cabo Frio's low-rainfall climate is unique to Brazil's southeastern coast which is mostly very wet (Araujo 2000). This is due, in part, to the Cabo Frio upwelling phenomenon, the ascent of a cold-water current rich in nutrients that promotes marine-life diversity and rich fishing grounds.

\section{Methods}

The ethnobotanical survey was based on traditional knowledge of local fishermen - the oldest male residents, born and raised in the neighborhood of Praia Grande where the headquarters of the fishermen's association is located.

During early visits to the headquarters of the Arraial do Cabo Marine Extractivist Reserve (Resex) and the local fishermen's association (APAC), an informant was selected for an interview from among the older fishermen who earn their living by fishing. After the interview, this informant named a second one, who indicated a third, and so forth. This is known as the "snowball" technique (Bailey 1994). A total of 14 key informants were interviewed (10\% of the fishermen belonging to the association); all were male, ranging in age from 50 to 84 years old. Fishing provides a livelihood for seven of these; four could not participate because of poor health and three did not wish to participate in the study.

Therefore seven key informants were identified and interviewed for the study, all of whom were male and who had considerable knowledgeable of the regional flora. The parents of these informants were born in the village of Arraial do Cabo, had grown up there, and made their living from fishing (residents with this background are known as "cabistas";
Fonseca-Kruel \& Peixoto 2004). Five of the key informants indicated useful plants in loco, a technique called "walk-in-the-woods" (Albuquerque \& Lucena 2004), and these plants were collected for identification. Before pressing, these plants were shown to the other informants together with a photograph of the entire plant in its habitat and details of the flower and fruit.

The interviews were recorded, reproduced and native restinga-forest species were identified and grouped into five use categories (construction, food, firewood, medicine, technology) adapted to this study from Galeano (2000), Albuquerque \& Andrade (2002a,b) and Fonseca-Kruel \& Peixoto (2004).

Included in the food category was any part of the plant that can be ingested, either raw or processed (like juices), used in human and animal food. The medicine category refers to the kind of plant used to heal and the disease being treated. The plants used to make furniture, build ships, repair boats, make poles used to haul in the fish nets, soap and utensils, in general, were placed in the technology category. The construction category included, for example, foundations for houses, beams to hold up the roof and walls, flooring and other uses. The firewood category included plants used for cooking in old stoves.

In monthly field trips from March 2000 to July 2001, we located several remnants of resting a forest as well as other vegetation types identified by the fishermen. We visited these fragments regularly to collect plants. Concomitantly, we used semi-structured interviews based on a previously prepared questionnaire. The interviews took place at the fishermen's association and on accompanied walks through the resting a forest (as recommended by Martin 1995) to collect botanical material and take notes on species use (Phillips \& Gentry 1993 a; Alexiades \& Sheldon 1996).

To gather additional data, we interviewed informants at the local fishermen's association (i.e., outside the study area), thus including elderly informants who could not go to the field. 
Interviews were carried out individually to avoid the influence of other informants. They were based on consensus between informants, that is, we calculated the relative importance of use directly from the degree of consensus of the selected informants (Phillips \& Gentry 1993 a,b). Our data on each useful species included Latin name, plant family, common name, life form, use(s), used part, and informant's name.

In the ethnobotanical analysis, we first calculated the use-value estimate of each species (Prance et al. 1987; Phillips \& Gentry 1993 a,b). The total use value of each species, by each informant, is defined as $\mathrm{UV}_{\text {is }}=\Sigma \mathrm{U}_{\text {is }}$ / $\mathrm{n}_{\mathrm{is}}$ (where $\mathrm{UV}_{\mathrm{is}}=$ the use-value of each species $s$ for each informant $i$; $U_{\text {is }}$ equals the number of uses mentioned in each event by informant $\mathrm{i}$, and $\mathrm{n}_{\mathrm{is}}$ equals the number of events for species s with informant i (Phillips \& Gentry 1993a). An "event" is defined as the process of asking one informant on one day about the uses they know for one species (Phillips \& Gentry 1993a).

Our estimate of the overall use value for each species $\mathrm{s}, \mathrm{UV}_{\mathrm{s}}$, is then: $\mathrm{UV}_{\mathrm{s}}=\Sigma \mathrm{UV}_{\text {is }}$ / $n_{s}$; where $n_{s}$, equals the number of informants interviewed for species $\mathrm{s}$. We then calculated the use-value estimate of each plant family (Phillips \& Gentry 1993 a,b); FUV $=\Sigma U V_{\mathrm{s}} /$ number of species; where FUV equals Family Use Value. This estimate allowed us to assess the importance given to each useful plant family by the traditional population (local fishermen). These indices are used as an integrated, quantified evaluation of the local intensity of resource use by the fishermen.

\section{Vegetation survey}

This study was carried out in a remnant restinga forest (1.5 ha area) using the survey method proposed by Gentry (1982) and used by Mendonza (1999). This method consists of sampling a 0.1-hectare area consisting of 10 transects, $50 \mathrm{~m} \times 2 \mathrm{~m}$, spaced c. $50 \mathrm{~m}$ apart. We measured all woody trees $(\mathrm{dbh} \geq 2.5 \mathrm{~cm})$ and vines (diameter $\geq 2.5 \mathrm{~cm}$ at soil level) and estimated tree height using a pruner pole. Plants were identified based on the literature, by comparison with herbarium specimens, or by a plant taxonomist. Voucher specimens are deposited in the herbarium of the Rio de Janeiro Botanical Garden (RB). Structural parameters follow Brower \& Zar (1984); diversity and eveness are based on Magurran (1988).

\section{Results and Discussion \\ Flora and vegetation structure}

In 0.1 ha of restinga forest at Arraial do Cabo, 296 individuals belonging to 41 species, 26 families and 36 genera were sampled. Total density was 2960 individuals per hectare and total dominance was $44 \mathrm{~m}^{2} /$ ha (Tab.1). Dead plants $(30 ; 9.2 \%)$ brought the total number of individuals up to 326. Shannon's diversity index was 2.69 nats/ind. (eveness $=0.73$ ).

When compared to other patches of resting a forest in the Cabo Frio region (studies using the same method and sample size), species richness and diversity values surpassed those found in a low forest (mean height $=6 \mathrm{~m}$ ) near the beach (Lobão \& Kurtz 2000), but were considerably less than those found in three taller forests on well-drained soils (Rezende 2004; Fernandes 2002, 2005; Tab. 2). The values were similar to those reported for a periodically flooded restinga forest at Restinga de Jurubatiba National Park on the northern coast of Rio de Janeiro state (Tab. 2), in a 0.5-hectare sample that excluded lianas (Oliveira 2000).

The diversity of this forest is low when compared to that of Atlantic forests. This is due not only to fewer species but also to structural oligarchy or dominance restricted to a few species (Tab. 1). Almost half (49\%) of total importance value is represented by the first three species.

No family shows significant species diversification in this forest. The most representative families, in terms of species richness, are Leguminosae, Sapindaceae, Myrtaceae and Rubiaceae (Tab.1), which are among the most species-rich in the restingas of Rio de Janeiro state (Araujo 2000).

Total basal area of $44 \mathrm{~m}^{2} /$ ha is high when compared to other restinga forests sampled 
Table 1 - Structural parameters $(\mathrm{dbh} \geq 2.5 \mathrm{~cm})$ in 0.1 ha of restinga forest at Arraial do Cabo $(\mathrm{Ni}=$ number of individuals; AF $=$ absolute frequency; $\mathrm{AD}=$ absolute density $; \mathrm{ADo}=$ absolute dominance; $\mathrm{RF}=$ relative frequency $\mathrm{RD}=$ relative density; $\mathrm{RDo}=$ relative dominance; $\mathrm{IV}$ = importance value).

\begin{tabular}{|c|c|c|c|c|c|c|c|c|c|}
\hline Families & Species & $\mathbf{N i}$ & $\begin{array}{l}\mathbf{A F} \\
(\%)\end{array}$ & $\begin{array}{c}\text { AD } \\
\text { (ind/ha) }\end{array}$ & $\begin{array}{c}\text { ADo } \\
\left(\mathrm{m}^{2} / \mathrm{ha}\right)\end{array}$ & $\begin{array}{l}\text { RF } \\
(\%)\end{array}$ & $\begin{array}{l}\text { RD } \\
(\%)\end{array}$ & $\begin{array}{r}\text { RDo } \\
(\%)\end{array}$ & IV \\
\hline Anacardiaceae & Schinus terebinthifolius Raddi & 108 & 100 & 1080 & 16.294 & 9.17 & 36.49 & 37.04 & 82.70 \\
\hline Sapotaceae & $\begin{array}{l}\text { Sideroxylon obtusifolium (Humb. ex Roem. } \\
\text { \& Schult.) T.D.Penn. }\end{array}$ & 25 & 70 & 250 & 14.148 & 6.42 & 8.45 & 32.16 & 47.03 \\
\hline Leguminosae & $\begin{array}{l}\text { Chloroleucon tortum (Mart.) Pittier ex Barneby } \\
\text { \& J.W.Grimes }\end{array}$ & 6 & 50 & 60 & 4.407 & 4.59 & 2.03 & 10.02 & 16.63 \\
\hline Myrtaceae & Campomanesia schlechtendaliana (O. Berg) Nied. & 21 & 70 & 210 & 1.122 & 6.42 & 7.09 & 2.55 & 16.07 \\
\hline Leguminosae & Inga laurina $(\mathrm{Sw}$.$) Willd.$ & 12 & 50 & 120 & 2.519 & 4.59 & 4.05 & 5.73 & 14.37 \\
\hline Myrtaceae & Myrrhinium atropurpureum Schott & 20 & 50 & 200 & 0.466 & 4.59 & 6.76 & 1.06 & 12.40 \\
\hline Meliaceae & Trichilia casaretti C.DC. & 9 & 50 & 90 & 0.512 & 4.59 & 3.04 & 1.16 & 8.79 \\
\hline Euphorbiaceae & Sapium glandulatum (Vell.) Pax & 5 & 50 & 50 & 0.597 & 4.59 & 1.69 & 1.36 & 7.63 \\
\hline Myrtaceae & Eugenia uniflora L. & 6 & 40 & 60 & 0.187 & 3.67 & 2.03 & 0.43 & 6.12 \\
\hline Sapindaceae & Allophylus puberulus Radlk. & 5 & 40 & 50 & 0.147 & 3.67 & 1.69 & 0.33 & 5.69 \\
\hline Piperaceae & Piper amalago var. medium (Jacq.) Yunck. & 4 & 30 & 40 & 0.637 & 2.75 & 1.35 & 1.45 & 5.55 \\
\hline Sapindaceae & Allophylus sp. & 7 & 30 & 70 & 0.141 & 2.75 & 2.36 & 0.32 & 5.44 \\
\hline Cactaceae & Brasilopuntia brasiliensis (Willd.) A.Berger & 5 & 30 & 50 & 0.420 & 2.75 & 1.69 & 0.95 & 5.40 \\
\hline Capparaceae & Capparis flexuosa (L.) L. & 4 & 30 & 40 & 0.228 & 2.75 & 1.35 & 0.52 & 4.62 \\
\hline Sapindaceae & Paullinia racemosa Wawra & 4 & 30 & 40 & 0.050 & 2.75 & 1.35 & 0.11 & 4.22 \\
\hline Apocynaceae & Forsteronia leptocarpa (Hook. \& Arn.) A.DC. & 4 & 30 & 40 & 0.027 & 2.75 & 1.35 & 0.06 & 4.17 \\
\hline Celastraceae & Maytenus obtusifolia Mart. & 5 & 20 & 50 & 0.028 & 1.83 & 1.69 & 0.06 & 3.59 \\
\hline Myrsinaceae & Myrsine parvifolia A.DC. & 3 & 20 & 30 & 0.284 & 1.83 & 1.01 & 0.65 & 3.49 \\
\hline$\underline{\text { Solanaceae }}$ & Cestrum laevigatum Schltdl. & 3 & 20 & 30 & 0.186 & 1.83 & 1.01 & 0.42 & 3.27 \\
\hline
\end{tabular}




\begin{tabular}{|c|c|c|c|c|c|c|c|c|c|}
\hline Families & Species & $\mathbf{N i}$ & $\begin{array}{l}\mathrm{AF} \\
(\%)\end{array}$ & $\begin{array}{c}\text { AD } \\
\text { (ind/ha) }\end{array}$ & $\begin{array}{c}\text { ADo } \\
\left(\mathrm{m}^{2} / \mathrm{ha}\right)\end{array}$ & $\begin{array}{l}\text { RF } \\
(\%)\end{array}$ & $\begin{array}{l}\mathrm{RD} \\
(\%)\end{array}$ & $\begin{array}{r}\text { RDo } \\
(\%)\end{array}$ & IV \\
\hline Simaroubaceae & Picramnia ramiflora Planch. & 6 & 10 & 60 & 0.064 & 0.92 & 2.03 & 0.15 & 3.09 \\
\hline Bignoniaceae & Arrabidaea conjugata (Vell.) Mart. & 3 & 20 & 30 & 0.062 & 1.83 & 1.01 & 0.14 & 2.99 \\
\hline Rubiaceae & Psychotria carthaginensis Jacq. & 3 & 20 & 30 & 0.020 & 1.83 & 1.01 & 0.04 & 2.89 \\
\hline Leguminosae & Zollernia glabra (Spreng.) Yakovlev & 2 & 20 & 20 & 0.102 & 1.83 & 0.68 & 0.23 & 2.74 \\
\hline Rhamnaceae & Scutia arenicola (Casar.) Reissek & 2 & 20 & 20 & 0.051 & 1.83 & 0.68 & 0.12 & 2.63 \\
\hline Verbenaceae & Aegiphila sellowiana Cham. & 2 & 20 & 20 & 0.027 & 1.83 & 0.68 & 0.06 & 2.57 \\
\hline Rubiaceae & Randia $\operatorname{armata}(\mathrm{Sw}$.$) DC.$ & 2 & 20 & 20 & 0.015 & 1.83 & 0.68 & 0.03 & 2.54 \\
\hline Sapindaceae & Paullinia weinmanniaefolia Mart. & 4 & 10 & 40 & 0.050 & 0.92 & 1.35 & 0.11 & 2.38 \\
\hline Combretaceae & Terminalia catappa $\mathrm{L}$ & 1 & 10 & 10 & 0.452 & 0.92 & 0.34 & 1.03 & 2.28 \\
\hline Malpighiaceae & Heteropterys coleoptera A.Juss. & 3 & 10 & 30 & 0.033 & 0.92 & 1.01 & 0.08 & 2.01 \\
\hline Anacardiaceae & Lithraea brasiliensis Marchand & 1 & 10 & 10 & 0.313 & 0.92 & 0.34 & 0.71 & 1.97 \\
\hline Leguminosae & $\begin{array}{l}\text { Inga subnuda subsp. luschnathiana } \\
\text { (Benth.) T.D.Penn. }\end{array}$ & 1 & 10 & 10 & 0.253 & 0.92 & 0.34 & 0.58 & 1.83 \\
\hline Ulmaceae & Trema micrantha (L.) Blume & 1 & 10 & 10 & 0.042 & 0.92 & 0.34 & 0.10 & 1.35 \\
\hline Rubiaceae & Guettarda viburnoides Cham. \& Schltdl. & 1 & 10 & 10 & 0.034 & 0.92 & 0.34 & 0.08 & 1.33 \\
\hline Bignoniaceae & Arrabidaea sp. & 1 & 10 & 10 & 0.011 & 0.92 & 0.34 & 0.03 & 1.28 \\
\hline Moraceae & Maclura aff. tinctoria (L.) D.Don. ex Steud. & 1 & 10 & 10 & 0.011 & 0.92 & 0.34 & 0.02 & 1.28 \\
\hline Ebenaceae & Diospyros inconstans Jacq. & 1 & 10 & 10 & 0.010 & 0.92 & 0.34 & 0.02 & 1.28 \\
\hline Simaroubaceae & Picramnia bahiensis Turcz. & 1 & 10 & 10 & 0.008 & 0.92 & 0.34 & 0.02 & 1.27 \\
\hline Solanaceae & Solanum inaequale Vell. & 1 & 10 & 10 & 0.008 & 0.92 & 0.34 & 0.02 & 1.27 \\
\hline Euphorbiaceae & Pera glabrata (Schott) Poepp. ex Baill. & 1 & 10 & 10 & 0.007 & 0.92 & 0.34 & 0.02 & 1.27 \\
\hline Urticaceae & Urera baccifera (L.) Gaudich. ex Wedd. & 1 & 10 & 10 & 0.006 & 0.92 & 0.34 & 0.01 & 1.27 \\
\hline Theophrastaceae & Jacquinia armillaris Jacq. & 1 & 10 & 10 & 0.005 & 0.92 & 0.34 & 0.01 & 1.27 \\
\hline & Total & 296 & & 2960 & 43.987 & 100 & 100 & 100 & 300 \\
\hline
\end{tabular}


Table 2 - Species richness and diversity of restinga and Atlantic forest sites on the coast of Rio de Janeiro state; dbh = diameter at breast height; H' - Shannon's diversity index; J - evenness; AF Atlantic Forest; SDF - Seasonally Dry Forest; RF - Restinga Forest. (-) no information.

\begin{tabular}{|c|c|c|c|c|c|c|c|c|}
\hline Source & $\begin{array}{l}\text { Study } \\
\text { Area }\end{array}$ & $\begin{array}{l}\text { dlbh } \\
(\mathrm{cm})\end{array}$ & $\begin{array}{c}\text { Area } \\
\text { (ha) }\end{array}$ & $\mathbf{H}^{\prime}$ & $\mathbf{J}$ & $\begin{array}{l}\text { Number } \\
\text { of Species }\end{array}$ & $\begin{array}{l}\text { Basal } \\
\text { Area } \\
\left(\mathbf{m}^{2} / \mathbf{h a}\right)\end{array}$ & Type \\
\hline $\begin{array}{l}\text { Melo \& } \\
\text { Mantovani (1993) }\end{array}$ & $\begin{array}{l}\text { Ilha do Cardoso } \\
\text { (SP) }\end{array}$ & $\geq 2.5$ & 1.0 & 3.64 & & 157 & 47.9 & $\mathrm{AF}$ \\
\hline Oliveira (2002) & Ilha Grande (RJ) & $\geq 2.5$ & 0.26 & 4.31 & - & 134 & 57.9 & $\mathrm{AF}$ \\
\hline Farág (1999) & Búzios (RJ) & $\geq 5.0$ & 0.5 & 4.00 & 0.84 & 124 & 32.0 & $\mathrm{AF}$ \\
\hline Sá(2006) & Búzios (RJ) & $\geq 2.5$ & 0.1 & 4.05 & 0.85 & 115 & 29.7 & SDF \\
\hline Sá(2006) & Cabo Frio (RJ) & $\geq 2.5$ & 0.1 & 3.78 & 0.85 & 84 & 20.9 & SDF \\
\hline $\begin{array}{l}\text { Lobão \& Kurtz } \\
\text { (2000) }\end{array}$ & $\begin{array}{l}\text { Búzios-Praia Gorda } \\
\text { (RJ) }\end{array}$ & $\geq 2.5$ & 0.1 & 2.52 & 0.76 & 26 & 21.8 & $\mathrm{RF}$ \\
\hline Fernandes (2002) & $\begin{array}{l}\text { Búzios-Manguinhos } \\
\text { (RJ) }\end{array}$ & $\geq 2.5$ & 0.1 & 3.59 & 0.83 & 72 & 30.0 & $\mathrm{RF}$ \\
\hline Resende (2004) & $\begin{array}{l}\text { Cabo Frio-Campos } \\
\text { Novos (RJ) }\end{array}$ & $\geq 2.5$ & 0.1 & 4.00 & 0.85 & 108 & 32.1 & $\mathrm{RF}$ \\
\hline Fernandes (2005) & $\begin{array}{l}\text { Cabo Frio-Tamoios } \\
\text { (RJ) }\end{array}$ & $\geq 2.5$ & 0.2 & 4.20 & 0.83 & 158 & 35.2 & $\mathrm{RF}$ \\
\hline Oliveira (2000) & Macaé (RJ) & $\geq 0.5$ & 0.5 & 2.79 & 0.73 & 45 & 32.9 & $\mathrm{RF}$ \\
\hline Silva et al. (1994) & Ilha do Mel (PR) & $\geq 5.0$ & 0.56 & 3.22 & 0.81 & 53 & 46.5 & $\mathrm{RF}$ \\
\hline Guedes et al. (2006) & Bertioga (SP) & $\geq 3.2$ & 0.24 & 3.70 & 0.88 & 67 & 27.7 & $\mathrm{RF}$ \\
\hline This study & Arraial do Cabo (RJ) & $\geq 2.5$ & 0.1 & 2.69 & 0.73 & 41 & 43.9 & $\mathrm{RF}$ \\
\hline
\end{tabular}

using the same method and sample size in the Cabo Frio region (Fernandes 2002, 2005; Rezende 2004; Lobão \& Kurtz 2000) and when compared to a seasonally flooded resting a forest in northern Rio de Janeiro state based on a 0.5 -hectare sample (Oliveira 2000) (Tab. 2). It also surpasses the basal area of seasonally dry forests in the Cabo Frio region investigated by Sá (2006) using the same method and sample size, and by Farág (1999) using a 0.5-hectare sample (Tab. 2). Reported basal areas for other restinga forests south of Rio de Janeiro are generally lower than that found in the present study (see Sugiyama, 1998; Guedes et al. 2006; Sztutman \& Rodrigues 2002). High basal area $\left(46.5 \mathrm{~m}^{2} / \mathrm{ha}\right)$ has been reported for a gradient of dry restinga to wet restinga forest in Paraná state (Silva et al.
1994 - this value is not strictly comparable since minimum diameter was $\mathrm{dbh} \geq 5 \mathrm{~cm}$ ). Most Atlantic rain forests have considerably higher basal area (e.g., Melo \& Mantovani 1994; Oliveira 2002), but this is not always the case and may be related to disturbance (Oliveira 2002; Silva \& Nascimento 2001).

According to Liebsch et al. (2007), biomass (basal area in this case) increases with the age of a forest or time after disturbance. The high basal area of the forest studied here would seem to indicate that this forest has not been disturbed for some time, which is not the case. There may be another explanation for the high basal area. The most important species (Schinus terebinthifolius and Sideroxylon obtusifolium) contain c. $70 \%$ of total basal area and also have high use values. The way in which 
these species are managed by the local population of fishermen could heavily influence their survival and growth within the forest.

The results of studies such as those of Anderson \& Posey (1985) on the management of cerrados by Kayapó Indians imply that many tropical ecosystems, long regarded as "natural" by researchers, may have been heavily influenced by native populations. To make an analogy with restingas, the forest fragment discussed herein may have been managed by several generations ofy the "shell-mound people". The Cabo Frio area is rich in shell mounds, and Scheel-Ybert $(1999 ; 2000)$ found evidence in these structures of management activities. Local informants state that they apply a "fisherman's ecology" when exploiting the resources of this fragment. This means that they do not cut or damage the "mother trees"; they use only the sprouts on these trees. The result may be the high basal area and high use value of the dominant species seen here.

In terms of structure, the most important species are Schinus terebinthifolius, Sideroxylon obtusifolium, Chloroleucon tortum, Campomanesia schlechtendaliana, Inga laurina and Myrrhinium atropurpureum (Tab.1). All species are common in the Cabo Frio area, with the exception of Terminalia catappa and Urera baccifera which are not native to restinga vegetation (Araujo 2000) and owe their presence to human disturbance. In the Cabo Frio region, farther to the north on the Búzios peninsula, Fernandes (2002) and Lobão \& Kurtz (2000) also reported $S$. terebinthifolius as one of the most important species based on high importance values attributed to relatively high dominance. In other areas of restinga forest (Tab. 2), including severely disturbed areas (Sá 1996), this species was not sampled or was rare (Rezende 2004). However, in areas that showed signs of selective cutting (Assumpção \& Nascimento 2000) it was among the 10 most important species in community structure.

Total number of plants per sample unit varied from 16 to 49 (dead plants included), while the number of species varied from 5 to 17. Sample units with fewer species were dominated by $S$. terebinthifolius. These units were located in a wetter area of the forest, with a thicker litter layer, that is periodically flooded during the rainy season (E.A. Mattos pers. comm. 2004). This area may also be flooded occasionally by seawater (Muehe 1994) or it may have been part of Holocene lagoon deposits some 3900 years B.P. (Turcq et al. 1999), and therefore contain saline soils. The presence of key species such as Jacquinia armillaris and S. obtusifolium in or near the forest is an indication of saline soils. This factor, together with man's use of the area, may explain the relatively low number of woody species, since in other study areas using the same sampling method and plot size (Tab. 2), restinga forests are much richer in species (Fernandes 2002, 2005; Rezende 2004).

Trees were the most representative life form $(44 \%)$, followed by shrubs $(39 \%)$, and vines $(6.7 \%)$. Most of the trees fell into the 4.5-7.5 m size class. Taller trees (up to $12.5 \mathrm{~m}$ ) were represented by $S$. obtusifolium, Inga laurina, and S. terebinthifolius. Tree diameters lie mainly between 2.5 and $5.5 \mathrm{~cm}$. The largest diameters belong to $S$. obtusifolium, $C$. tortum, and S. terebinthifolius.

Many trees showed trunk damage (from selective felling, wind, fire, disease, etc.) as seen by the large number of multiple stems $(46 \%)$. Studies in the restingas of Rio de Janeiro and São Paulo states have shown that some woody species have great resprouting capacity (Cirne \& Scarano 1996; Sá 1996; 2002; Carvalhaes \& Mantovani 1998; Assumpção \& Nascimento 2000). Resprouting seems to be an important mechanism for regeneration in disturbed restinga habitats, giving species with this capacity an advantage over others. Structural characteristics of secondary restinga vegetation most likely reflect this capacity. In the sample area, species with high importance values also have high percentages of plants with sprouts (e.g., $S$. obtusifolium, I. laurina, S. terebinthifolius). 
Gentry (1995) found an average of 5070 species in lowland dry forests (rainfall < $1600 \mathrm{~mm} /$ year) using similar methodology. This number is considerably higher than that of the present study. He made no reference to disturbance in the study areas. The Arraial do Cabo study site is highly disturbed as seen by the many stem sprouts. Fire is probably recurrent here, as was observed three months after we finished our field work, when eight of the ten transects showed signs of fire.

Schinus terebinthifolius is a highly tillered species with high density and importance values (Fig. 1). This pioneer species is prominent in some vegetation types of the Cabo Frio area, mainly in wet areas (Lobão \& Kurtz 2000). Species abundance suggests tolerance to limiting factors that occur in the area such as high soil salinity due to the proximity of the Araruama lagoon and salt flats, as well as frequent strong winds. Another abundant many-tillered species is S. obtusifolium. Anthracological studies from local shell mounds have shown that the most abundant charcoal remains were from the $S$. obtusifolium (Scheel-Ybert 2000). Prehistoric huntergatherers may have used this wood widely and also consumed the small, black fruits. ScheelYbert (2000) suggests that social groups managed this species, because it is often found growing near the shell mounds.

\section{Ethnobotany}

Local fishermen use $57 \%$ of the botanical families and $46 \%$ of the species occurring in the study area. These taxa include $80 \%$ of the individuals included in the sampled area. They mentioned 22 different uses for these species (Tab. 3). A single species may have up to 4 different uses, but most have one or two. There were 296 events, resulting in a total of 422 use citations for this remnant restinga forest.

Use categories with the most species were technology (47\%), food (42\%), followed by construction (36.8\%), firewood (36.8\%) and medicine (21\%). In this study, it is important to note that useful woody species were related to subsistence activities rather than commerce, as in Galeano (2000).

Cunha \& Albuquerque (2006) in an ethnobotanical study in an Atlantic forest fragment in northeast Brazil, using similar methods and use categories, obtained different results. The most important use categories were construction (39\%), firewood (21\%), technology (19\%), food (8.7\%) and medicine (8.2\%). At Arraial do Cabo, the most important categories were technology (47\%) and food $(42 \%)$, that is, the local community regards the restinga as a source of nutrients, with many edible fruits, and also as a source of plants used to make fishnets, tool handles, utensils and wood for boat repairs.

The stem was the most useful part of the plant collected by the fishermen (60\%), followed by fruit (23\%), leaves (8.5\%), bark $(5.7 \%)$ and root $(2.9 \%)$. This is similar to what was reported by Cunha and Albuquerque (2006), where wood and fruits were the most extracted plant parts from the forest.

Species and family use values (UVs) plus the number of uses, interviews and informants are given in Table 3. Most species had low UVs. The highest UVs belonged to $S$. terebinthifolius, I. laurina, Cestrum

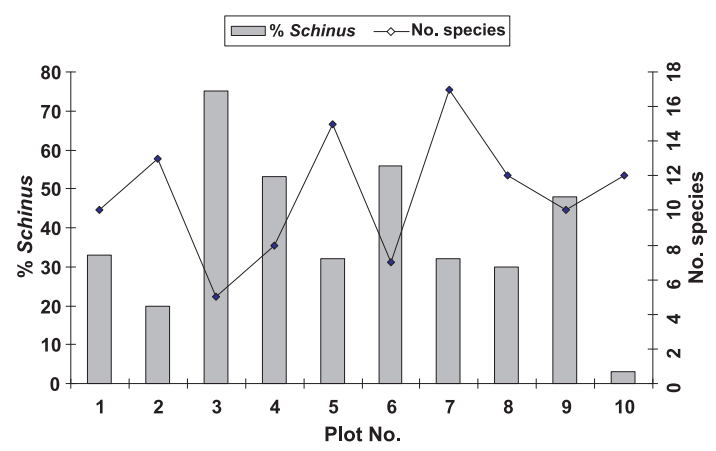

Figure 1 - Number of species and percentage of Schinus terebinthifolius plants per plot in 0.1 ha of restinga forest at Arraial do Cabo, RJ. 
Table 3 - Useful species $(\mathrm{dbh} \geq 2.5)$ sampled in 0.1 ha of restinga forest at Arraial do Cabo Municipality, Rio de Janeiro, Brazil. (UV - total species use value; Use categories: Co - construction; Fo - food; Fu - firewood; Me - medicine; Te - technology).

\begin{tabular}{|c|c|c|c|c|c|c|}
\hline Species & $\begin{array}{c}\text { Vernacular } \\
\text { name }\end{array}$ & $\mathbf{U V} \mathbf{V}_{\mathrm{s}}$ & $\begin{array}{l}\text { Number } \\
\text { of Events }\end{array}$ & $\begin{array}{l}\text { Number of } \\
\text { Informants }\end{array}$ & Uses & $\begin{array}{l}\text { Collector's } \\
\text { Number }\end{array}$ \\
\hline Schinus terebinthifolius & aroeira & 2.38 & 14 & 6 & $\mathrm{Me}, \mathrm{Fu}, \mathrm{Fo}, \mathrm{Te}$ & VSF 488, 535 \\
\hline Inga laurina & ingá, farinha-seca & 2.13 & 12 & 6 & $\mathrm{Fu}, \mathrm{Fo}, \mathrm{Te}, \mathrm{Co}$ & VSF 268,531 \\
\hline Cestrum laevigatum & canema & 1.9 & 14 & 5 & $\mathrm{Me}, \mathrm{Te}$ & VSF 549,561 \\
\hline $\begin{array}{l}\text { Campomanesia } \\
\text { schlechtendaliana }\end{array}$ & gabiroba & 1.19 & 16 & 7 & Fo, $\mathrm{Te}, \mathrm{Co}$ & VSF469 \\
\hline Sideroxylon obtusifolium & saputiquiaba & 1.09 & 14 & 7 & $\mathrm{Co}, \mathrm{Te}$ & VSF 472, 519 \\
\hline Brasilopuntia brasiliensis & arumbeba & 1.05 & 13 & 6 & Fo & VSF485 \\
\hline Piper amalago var. medium & aperta-ruão & 1.0 & 7 & 3 & $\mathrm{Me}$ & VSF 514,512 \\
\hline Scutia arenicola & arribeira, ribeira & 1.0 & 5 & 3 & $\mathrm{Me}, \mathrm{Fo}, \mathrm{Te}$ & VSF536 \\
\hline Terminalia catappa & amendoeira & 1.0 & 12 & 6 & Fo & VSF510 \\
\hline Capparis flexuosa & timbó & 0.86 & 7 & 5 & Fo, Te, Co & VSF 548, 555 \\
\hline $\begin{array}{l}\text { Inga subnuda subsp. } \\
\text { luschnathiana }\end{array}$ & ingá & 0.8 & 6 & 5 & $\mathrm{Fo}, \mathrm{Te}, \mathrm{Co}$ & VSF516 \\
\hline Myrsine parvifolia & capororoca & 0.8 & 9 & 5 & $\mathrm{Fu}$ & VSF 209,352 \\
\hline Eugenia uniflora & pitanga & 0.6 & 7 & 5 & $\mathrm{Fu}, \mathrm{Fo}$ & VSF 229,358 \\
\hline Chloroleucon tortum & jacaré & 0.5 & 10 & 6 & $\mathrm{Fu}$ & VSF576 \\
\hline Picramnia ramiflora & imbiu & 0.5 & 5 & 4 & $\mathrm{Fu}$ & VSF560 \\
\hline Trema micrantha & corindiba & 0.5 & 8 & 4 & $\mathrm{Te}$ & VSF570 \\
\hline Allophylus puberulus & estaladeira & 0.25 & 7 & 6 & $\mathrm{Fu}$ & VSF 509,518 \\
\hline Maytenus obtusifolia & papagaio & 0.25 & 5 & 4 & $\mathrm{Fu}$ & VSF473 \\
\hline Myrrhinium atropurpureum & - & 0.2 & 7 & 5 & $\mathrm{Fu}$ & VSF 528, 562 \\
\hline
\end{tabular}

laevigatum, C. schlechtendaliana, S. obtusifolium, Brasilopuntia brasiliensis and T. catappa. These species were the most frequently mentioned in the 296 events, by the greatest number of informants.

Only a few species had high use values, similar to what Galeano (2000) found in the Choco, Colombia, where high use values were concentrated in only four species, while most species had low use values. A similar situation has been found in other areas, such as gallery forests in Pernambuco (Ferraz et. al. 2006), a semi-arid region in Pernambuco state (Albuquerque et. al. 2005). It seems possible that use patterns may alter the structure of the forest. In the present study, for example, the species with the highest use values are also the dominant species (i.e., those that contribute most to total basal area). However, this possibility must be examined in more detail.

The families with the highest family use values (FUVs) were Anacardiaceae (2.1), Solanaceae (1.6), Rhamnaceae (1.3), Leguminosae (1.15), and Sapotaceae (1.14), because they were indicated by most of the informants in the interviews and presented multiple uses, associated with firewood, construction and/or consumption. Cunha \& Albuquerque (2006) also report that the largest use of the plants is related to obtaining wood to be used in building homes, producing firewood and charcoal; the most frequent species were Tapirira guianensis Aubl. (Anacardiaceae) and another Anacardiaceae, Thyrsodium schomburgkianum Benth. and others. 
Anacardiaceae had the greatest use values, due to $S$. terebinthifolius, an important plant resource in restingas. This species has multiple uses, such as technology (from the bark and root, a dye is extracted for fishnets), firewood, medicinal (bark used in traditional medicine as antiseptic and cicatrizing agent) and food (fruits for both birds and humans, mostly children). S. terebinthifolius and $S$. obtusifolium were cited by all fishermen as being useful. The former had three main use types: medicinal (anti-inflammatory, healing and antiseptic), technological (extraction of red pigment from root and stem for dyeing fish nets, cited mainly as happening "in the past"), construction (rafters, also, mainly "in the past"). The most common use cited for this species was pigment extraction for dyeing fish nets to protect against attack by fish and other animals (Kneip \& Machado 1993). Today, however, this is no longer done because fish numbers have declined, greatly reducing attacks on the nets. The extensive use of nylon nets has also contributed to this change.

According to Scheel-Ybert (1999), $S$. obtusifolium is an interesting species because it also is abundant in most of the archeological sites studied in southeastern Rio de Janeiro state, and is today very common in the vicinity of shell mounds. This association leads us to believe that this species may have been managed by the shell-mound people. It may have begun accidentally, and then was encouraged because of the edible fruits (Scheel-Ybert 1999, 2000). It should also be pointed out that restinga vegetation is very rich in legumes, with edible seeds, and many other fruit species (belonging to the genera Eugenia, Myrcia, Myrciaria, Psidium, Pouteria, and others). Many edible fruits may possibly have been dispersed by man and wild animals in this region.

Sideroxylon obtusifolium wood is used for boat repairs and to make the framework of boats and boat battens. According to the fishermen, it is "one of the most durable woods there is. It does not split easily and is impermeable." So, boats made or repaired with this wood "last up to 150 years".

Cestrum laevigatum was also indicated by most informants as useful, mainly, in traditional medicine. The leaves are collected, steeped in alcohol, and used for rubbing and massaging fatigued limbs and shoulder muscles.

Inga laurina, C. schlechtendaliana, B. brasiliensis, and T. catappa are appreciated mainly for their fruits. Even today, when the fishermen are working along the beach, they collect these fruits in the restinga. In the past, the wood of $I$. laurina and $C$. schlechtendaliana was used for building houses; I. laurina is used to repair boats. Another important species at the study site is C. tortum (used in construction and as firewood).

Of all useful species, $47.3 \%$ had some use type in technology. This category includes the construction and repair of boats, needles to make and repair fish nets, poles used to haul in fish nets and to transport fish, soap making and utensils in general. The species in this category belong to eight botanical families (53.3\% of the useful families), the most important being Leguminosae, Myrtaceae, and Sapotaceae, with uses related to boat repair and construction.

The food and construction categories were next in use frequency; $42.1 \%$ and $36.8 \%$ of total useful species, respectively. The eight species used for food belong to six families: Anacardiaceae, Cactaceae, Combretaceae, Leguminosae, Myrtaceae, and Rhamnaceae. Here, the part extracted is always the fruit. Seven species belonging to five families (mainly Leguminosae and Myrtaceae) are used for building homes.

In traditional Indian populations in Brazil, the use of plants as food varies from $21.8 \%$ to 40.4\% (Prance 1987; Balée 1987). Among seashore inhabitants, food use percentage varies from $17.4 \%$ to $51 \%$ (Begossi et al. 1993; Hanazaki et al. 1996; Rossato et al. 1999; Hanazaki et al. 2000) and a large percentage of the plants used are cultivated. 
For the interviewees the food category contributes with $42.1 \%$ of the inventoried species but all are species native to the restingas. Of the useful species, $36.8 \%$ were used as firewood mainly for cooking. Seven species belonging to five families (33.3\% of all useful families) were related to this use category.

Three species (21\% of all useful species) were used for medicinal purposes: $S$. terebinthifolius (anti-inflammatory, cicatrizing agent, antiseptic), Piper amalago (bath to ward off the "evil-eye" and bad spirits), and $C$. laevigatum (cicatrizing agent, antiseptic, bath as medicine for conjunctivitis). The low percentage of medicinal species $(7.9 \%)$ related to the total inventoried species may have been caused by the inventory inclusion criteria (only woody plants), or according to Voeks (1996) and Cunha \& Albuquerque (2006), by the fact that most plants used as medicine by many populations are herbs.

Through the relationship of structural vegetation parameters and use data, that together provide important information for better understanding of the man-nature relationship, it was possible to verify that there is a "vocation" for wood exploitation in this community, since the species with the largest use values are among those from which the wood itself is used as a resource for the community.

\section{Conclusions}

The informants at Arraial do Cabo retain and preserve knowledge of the use of $46 \%$ of the species surveyed in a remnant restinga forest belonging to the Arraial do Cabo Marine Extractivist Reserve. This knowledge is an important attribute for the sustainable management and conservation of local ecosystems.

The study area is disturbed by extensive tree cutting and fire, the result of the activities of persons outside the community of fishermen, who aim to pasture cattle in the area or to build small houses. In spite of this, regeneration is taking place as observed by tillering and resprouting of $46 \%$ of the stems.
The fishermen routinely recognize in the field many species from the restinga used for wood and/or useful fibers, for making needles to sew fish nets, boat hulls and repairs in general, as well as poles to haul in and transport fish nets. They also know useful plants for soap making and utensils. Useful plants for technological purposes were the most commonly cited.

The plants indicated as medicinal were not well represented probably due to the method used which sampled only trees, shrubs, and vines. In many studies in the restinga, the plants mentioned as medicinal are mainly herbs found in open formations and on dunes.

The study area, although strongly disturbed, still preserves a representative contingent of the restinga forests of Rio de Janeiro. Most of the species are native to restinga vegetation. Among the inventoried species, Jacquinia armillaris (=Jacquinia brasiliensis) is considered Vulnerable according to the Official List of Species of the Brazilian Flora Threatened with Extinction.

\section{Acknowledgements}

This study was part of the first author's Master's Thesis, from the Universidade Federal Rural do Rio de Janeiro. We gratefully acknowledge the generous support provided by the local fishermen of Arraial do Cabo for their teachings and hospitality. Thanks are also due to the Associação de Pescadores de Arraial do Cabo (APAC; AREMAC), IBAMA in Arraial do Cado and IEAPM (Instituto de Estudos do Mar "Almirante Paulo Moreira") for support during field trips; to CAPES (Coordenação de Aperfeiçoamento de Pessoal de Nível Superior) and the Environmental Sciences Graduate Course, Universidade Federal Rural do Rio de Janeiro, for support and the scholarship granted to the first author; to botanists G. Barroso, H. C. Lima, E. F. Guimarães, C. G. Pinto, G. Somner, L. D. A. Freire, B. Kurtz and R. Marquete for identification of the botanical material. We wish to thank Prof. Dr. Montserrat Rios, Gustavo S. Kruel, and Prof. Dr. Gabriel Bernardello for their valuable contributions to this manuscript. 


\section{REFERENCES}

Adams, C. 2000. As populações caiçaras e o mito do bom selvagem: a necessidade de uma nova abordagem interdisciplinar. Revista de Antropologia 43(1): 145-181.

Alexiades, M. N. \& Sheldon, J. W. (eds.). 1996. Selected guidelines for ethnobotanical research: a field manual. (Advances in Economic Botany, n. 10). New York, New York Botanical Garden, 306p.

Albuquerque, U. P. \& Andrade, L. H. C. 2002a. Conhecimento botânico tradicional e conservação em uma área de caatinga no estado de Pernambuco, Nordeste do Brasil. Acta Botanica Brasilica 16(3): 273-285.

Albuquerque, U. P. \& Andrade, L. H. C. 2002 b. Uso dos recursos vegetais da caatinga: o caso do agreste do estado de Pernambuco (Nordeste do Brasil). Interciencia 27(7): 336-345.

Albuquerque, U. P.; Andrade, L. H. C. \& Silva, A. C. O. 2005 . Use of plant resources in a seasonal dry forest (northeastern Brazil). Acta Botanica Brasilica 19(1): 1-16.

Albuquerque, U. P. \& Lucena, R. F. P. 2004. Métodos e técnicas para coleta de dados. In: Albuquerque, U. P. (org.). Métodos e técnicas na pesquisa etnobotânica. Ed. NUPEEA, Recife. Pp. 37-55.

Anderson, A. B. \& Posey, D. A. 1985. Manejo de cerrado pelos índios Kayapó. Boletim do Museu Paraense Emílio Goeldi, Ser. Botânica 2(1): 77-98.

Araujo, D. S. D. 1997. Cabo Frio Region. In: Davis, S. D.; V.H. Heywood, O. HerreraMacBryde, J. Villa-Lobos \& A. C. Hamilton (eds.). Centres of plant diversity: a guide and strategy for their conservation. Vol. 3. The Americas, WWF/IUCN, Oxford. Pp. 373-375.

Araujo, D. S. D. 2000. Análise florística e fitogeográfica das restingas do estado do Rio de Janeiro. Tese de Doutorado. Universidade Federal do Rio de Janeiro, Instituto de Biologia, Rio de Janeiro.
Araujo, D. S. D. \& Maciel, N. C. 1998. Restingas fluminenses: biodiversidade e preservação. Boletim FBCN 25: 27-51.

Assumpção, J. \& Nascimento, M. T. 2000. Estrutura e composição florística de quatro formações vegetais de restinga no complexo lagunar Grussaí/Iquipari, São João da Barra, RJ, Brasil. Acta Botanica Brasilica 14(3): 301-315.

Balée, W. 1986. Análise preliminar de inventário florestal e a etnbotânica Ka'apor (Ma). Boletim Museu Paraense Emílio Goeldi, Ser. Botânica 2(2): 141-167.

Balée, W. 1987. A etnobotânica quantitativa dos índios Tembé (rio Gurupi, Pará). Boletim Museu Paraense Emílio Goeldi, Ser. Botânica 3(1): 29-50.

Bailey, K. 1994. Methods of social research. The Free Press, New York.

Barbiére, E. B. 1984. Cabo Frio e Iguaba Grande, dois microclimas distintos a um curto intervalo espacial. In: Lacerda, L. D.; Araujo, D. S. D.; Cerqueira, R. \& Turcq, B. (eds.). Restingas: origem, estrutura, processos. CEUFF, Niterói. Pp. 3-13.

Begossi, A. 1996. Uses of ecological methods in ethnobotany: diversity indices. Economic Botany 50(3): 280-289.

Begossi, A.; Leitão-Filho, H. F. \& Richerson, R. J. 1993. Plant uses in a Brazilian coastal fishing community (Buzios Island). Journal of Ethnobiology 13(2): 233-256.

Boom, B. M. 1990. Useful plants of the Panare Indians of the Venezuelan Guayana. Advances in Economic Botany 8: 57-76.

Brower, J. E. \& Zar, J. H.1984. Field \& laboratory methods for general ecology. W.C. Brown Publishers, Duduque, 226p.

Carvalhaes, M. A. \& Mantovani, W. 1998. Florística de mata sobre restinga na Juréia, Iguape-SP. In: Anais do IV Simpósio de Ecossistemas Brasileiros. Vol. 2. Águas de Lindóia, SP. Acad. Ci. Est.. São Paulo. Pp. 37-48.

Cirne, P. \& Scarano, F. R. 1996. Rebrotamento após o fogo de Andira legalis (Leguminosae) em restinga fluminense. In: Miranda, H. 
S.; Saito, C. H.; Dias, B. F. S. (eds.). Impactos de queimadas em áreas de cerrado e restinga. Anais do $3^{\circ}$. Congresso de Ecologia do Brasil. ECL/UNB, Brasília. Pp. 128-136.

Chazdon, R. L. \& Coe, F. G. 1999. Ethnobotany of woody species in second-growth, oldgrowth, and selectively logged forests of Northeastern Costa Rica. Conservation Biology 13(6): 1312-1322.

Cunha, L. V. F. C. \& Albuquerque, U. P. 2006. Quantitative ethnobotany in the Atlantic Forest fragment of northeastern Brazil implications to conservation. Environmental Monitoring and Assessment 114: 1-25.

Diegues, A. C. S. 1994. Omito moderno da natureza intocada. NUPAUB, São Paulo, 163p.

Farág, P. R. C. 1999. Estrutura do estrato arbóreo de mata litorânea semicaducifólia sobre solo arenoso no município de Búzios, RJ. Dissertação de Mestrado. Universidade Federal do Rio de Janeiro, Rio de Janeiro.

Fernandes, D. S. 2002. Florística e fitossociologia de um trecho de floresta de restinga na praia de Manguinhos, Armação de Búzios/RJ. Monografia de Bacharelado. Universidade Santa Úrsula, Rio de Janeiro.

Fernandes, D. S. 2005. Estrutura de uma floresta seca de restinga em Cabo Frio, Rio de Janeiro. Dissertação de Mestrado. Escola Nacional de Botânica Tropical, Rio de Janeiro.

Ferraz, J. S. F.; Albuquerque, U. P. \& Meunier, I. M. J. 2006. Valor de uso e estrutura da vegetação lenhosa às margens do riacho do Navio, Floresta, PE, Brasil. Acta Botanica Brasilica 20(1): 125-134.

Figueiredo, G. M.; Leitão-Filho, H. \& Begossi, A. 1993. Ethnobotany of Atlantic forest coastal communities: diversity of plant uses in Gamboa (Itacuruça Island, Brazil). Human Ecology 2(4): 419-430.

Figueiredo, G. M.; Leitão-Filho, H. \& Begossi, A. 1997. Ethnobotany of Atlantic Forest communities. II. Diversity of plant uses at Sepetiba Bay (SE-Brazil). Human Ecology 21: 419-430.

Fonseca-Kruel, V. S. \& Peixoto, A. L. 2004. Etnobotânica na Reserva Extrativista
Marinha de Arraial do Cabo, RJ, Brasil. Acta Botanica Brasilica 18(1): 177-190.

Galeano, G. 2000. Forest use at the Pacific Coast of Chocó, Colombia: a quantitative approach. Economic Botany 54(3): 358-376.

Gentry, A. H. 1982. Patterns of Neotropical plant diversity. Evolutionary Biology 15: 1-84.

Gentry, A. H. 1995. Diversity and floristic composition of neotropical dry forests. In: Bullock, S. H.; Mooney, H. A. \& Medina, E. (eds.). Seasonally dry tropical forests. Cambridge University Press, Cambridge. Pp. 146-194.

Guedes, D.; Barbosa, L. M. \& Martins, S. E. 2006. Composição florística e estrutura fitossociologica de dois fragmentos de floresta de restinga no Município de Bertioga, SP, Brasil.Acta Botanica Brasilica 20: 299-311.

Hanazaki, N.; Leitão-Filho, H. F. \& Begossi, A. 1996. Uso de recursos na Mata Atlântica: o caso da Ponta do Almada (Ubatuba, Brasil). Interciencia 21(6): 268-276.

Hanazaki, N.; Tamashiro, J. Y; Leitão-Filho, H. \& Begossi, A. 2000. Diversity of plant uses in two caiçara communities from the Atlantic Forest coast, Brazil. Biodiversity and Conservation 9: 597-615.

Kneip, L. M. \& Machado, L. M. C. 1993. Os ritos funerários das populações préhistóricas de Saquarema, RJ: sambaquis da Beirada, Moa e Pontinha. Documento de Trabalho, Série Arqueologia 1: 1-76.

Kristensen, M. \& Lykke, A. M. 2003. Informantbased valuation of the use and conservation preferences of savanna trees in Burkina Faso. Economic Botany 57(2): 203-217.

Liebsch, D.; Goldenberg, R. \& Marques, M. C. M. 2007. Florística e estrutura de comunidades vegetais em uma cronoseqüência de Floresta Atlântica no estado do Paraná, Brasil. Acta Botanica Brasilica 21: 983-992.

Lima, R. X.; Silva, S. M.; Kuniyoshi, Y. S. \& SilvaL. B. 2000. Etnobiologia de comunidades continentais da Área de Proteção Ambiental de Guaraqueçaba, Paraná, Brasil. Etnoecológica 4(6): 33-55. 
Lobão, A. Q. \& Kurtz, B. C. 2000. Fitosociologia de um trecho de mata de restinga na Praia Gorda, Município de Armação de Búzios, RJ. In: Anais do IV Simpósio de Ecossistemas Brasileiros. Vol. 3. ACIESP, São Paulo. Pp. 66-73.

Magurran, A. E. 1988. Ecological diversity and its measurement. Princeton University Press, New Jersey, 179p.

Martin, G. J. 1995. Ethnobotany: a people conservation manual. Chapman \& Hall, London; New York, 268p.

Melo, M. M. R. F. \& Mantovani, W. 1994. Composição florística e estrutura de trecho de mata atlântica de encosta na Ilha do Cardoso (Cananéia, SP, Brasil). Boletim do Instituto de Botânica 9: 107-158.

Mendonza-C. H. 1999. Estructura y riqueza florística del bosque seco tropical en la región Caribe y el Valle del Río Magdalena, Colombia. Calladsia 21(1): 70-94.

Muehe, D. 1994. Lagoa de Araruama: geomorfologia e sedimentação. Cadernos Geociência IBGE 10: 53-62.

Oliveira, R. C. 2000. Estrutura do componente arbóreo da mata periodicamente inundada do Parque Nacional da Restinga de Jurubatiba, Município de Carapebus, Rio de Janeiro, RJ. Dissertação de Mestrado. Universidade Federal do Rio de Janeiro, Rio de Janeiro.

Oliveira, R. R. 2002. Ação antrópica e resultantes sobre a estrutura e composição da Mata Atlântica na Ilha Grande, RJ. Rodriguésia 53(82): 25-32.

Phillips, O. 1996. Some quantitative methods for analyzing ethnobotanical knowledge. In: Alexiades, M. (ed.). Selected guidelines for ethnobotanical research: a field manual.The New York Botanical Garden, New York. Pp.171-197.

Phillips, O. \& Gentry, A. H. 1993a. The useful plants of Tambopata, Peru. I: Statistical hypotheses tests with a new quantitative technique. Economic Botany 47: 33-43.

Phillips, O. \& Gentry, A. H. 1993b. The useful woody plants of Tambopata, Peru. II:
Further statistical tests of hypotheses in quantitative ethnobotany. Economic Botany 47: 15-32.

Phillips, O.; Gentry A. H.; Reynel, C.; Wilkin, P. \& Gálvez-Durand B. C. 1994. Quantitative ethnobotany and Amazonian conservation. Conservation Biology 8(1): 225-248.

Prado, S. M. 2002. Da anchova ao salário mínimo: uma etnografia sobre injunções de mudança social em Arraial do Cabo, RJ. Eduff, Niterói, 145p.

Prance, G. T. 1987. Etnobotânica de algumas tribos amazônicas. In: Suma etnológica brasileira. Vol. 1, Vozes, Petrópolis; FINEP, Rio de Janeiro. Pp. 119-134.

Prance, G. T.; Balée, W.; Boom, B. M. \& Carneiro, R. L. 1987. Quantitative ethnobotany and the case for conservation in Amazonia. Conservation Biology 1(4): 296-310.

Reis, M.; Mariot, A. \& Di-Stasi, L. C. 2000. Manejo de populações naturais de plantas medicinais na Floresta Atlântica. In:Diegues, A. C. \& Viana, V. M. (org.). Comunidades tradiconais e manejo dos recursos naturais da Mata Atlântica. Nupaub/ Lastrop/USP, São Paulo. Pp. 95-102.

Rezende, G. S. Z. 2004. Estrutura de um trecho da floresta de restinga da Estação Rádio Marinha Campos Novos - Cabo Frio, RJ. Monografia de Bacharelado. Universidade Federal Rural de Rio de Janeiro, Rio de Janeiro, 39p.

Rossato, S. C.; Leitão-Filho, H. F.; Begossi, A. 1999. Ethnobotany of caiçaras of the Atlantic Forest Coast (Brazil). Economic Botany 53(4): 387-395.

Sá, C. F. C. 1996. Regeneração em áreas de floresta de restinga na Reserva Ecológica Estadual de Jacarepiá, Saquarema-RJ.: I - Estrato herbáceo. Arquivos do Jardim Botânico do Rio de Janeiro 34(1): 177-192.

Sá, C. F. C. 2006. Estrutura, diversidade e conservação no Centro de Diversidade Vegetal de Cabo Frio, Rio de Janeiro, Brasil. Tese de Doutorado. Universidade Federal do Rio de Janeiro, Rio de Janeiro. 
Scheel-Ybert, R. 1999. Paleoambiente e Paleontologia de populações sambaquieiras do sudeste do estado do Rio de Janeiro. Revista do Museu de Arqueologia e Etnologia, São Paulo 9: 43-59.

Scheel-Ybert, R. 2000. Os vegetais na vida dos sambaquieiros. Ciência Hoje 28(165): 26-31.

Silva, G. C. \& Nascimento, M. T. 2001. Fitossociologia de um remanescente de mata sobre tabuleiros no norte do estado do Rio de Janeiro (Mata do Carvão). Revista Brasileira de Botânica 24: 51-62.

Silva, S. M.; Britez, R. M.; Souza, W. S. \& Joly, C. A. 1994. Fitossociologia do componente arbóreo da floresta de restinga da Ilha do Mel, Paranaguá, PR. In: Anais III Simpósio de Ecossistemas da Costa Brasileira, Serra Negra, ACIESP vol. 3. Pp. 33-48.

Silva, V. C. F. 2000. Pesca e uso comunitário do espaço costeiro na Ilha do Cardoso litoral sul de São Paulo - Brasil. In: Diegues, A. C. \& Viana, M. V. (orgs.). Comunidades tradicionais e manejo dos recursos naturais da Mata Atlântica. NUPAUB, São Paulo. Pp. 123-130

Sugiyama, M.1998. Estudo de florestas da restinga da Ilha do Cardoso, Cananéia, São Paulo, Brasil. Boletim do Instituto de Botânica 11: 119-159.

Sztutman, M. \& Rodrigues, R. R. 2002. O mosaico vegetacional numa área de floresta contínua da planície litorânea, Parque Estadual da Campina do Encantado, Pariquera-Açu, SP. Revista Brasileira de Botânica 25: 161-176.

Turcq, B.; Martin, L.; Flexor, J. M.; Suguio, K.; Pierre, C. \& Tasayaco-Ortega, L. 1999. Origin and evolution of the quaternary coastal plain between Guaratiba and Cabo Frio, State of Rio de Janeiro, Brazil. In: Knoppers, B.; Bidone, E. D. \& Abrão, J. J. (eds.). Environmental geochemistry of coastal lagoon systems of Rio de Janeiro, Brazil. Série Geoquímica Ambiental, n.6. Pp. 25-46.

Voeks, R. A. 1996. Tropical forest healers and habitat preference. Economic Botany 50: 381-400. 